271 : 整形外科的な対応で，順調な経過をとった頸肩 腕障害の患者之順調な経過をとらず，いわわする難治と考 光た患者群の 2 群炕ついて，検查手技の有效性を検討し たものである. 以下の質铤が行われた。

質問(田尻)；初診時に難治例かどうかの区別ができる のか.

答；初診時に多愁訴で西るにもかかわらず，所見の少 ない例が，難治の傾向が岕るが，初診時にそとををめる ことは考党ていない，経過を見ていて，難治と思われる 症例には心理学的な検討が必要之考兄ている.

質問 (大道); 精神面の検討はどのようにされたのか。 精神科が参加しているのか.

答; 心理療法士が行なって数り, 精神科医は参加して いない。

質問 (上畑)；整形外科のみ，難治例はどう区別したの か.

上記した通りの答があった。

質問(慶大・桜井)；右上の表の対照は何をとられたの か.

答; 看護学院の学生でず.

演題 272 と 274 は, 作業姿勢之局所負担との関連を, 前者は農作業の現場調査から，後者は実験的打鋌作業の 面から，明らかにする報告であった．272 亿関しては， 農作業の場合, 季節により作業内容が買なり, 各種の作 業の長期的影響が自覚症汉反映している可能性が指摘さ れた（福地，滋賀医大）が，対像作業江和汀る「疲学部 位調べ」を行なえば，作業姿勢々局所疲労之の関連をも っと明確にできるだらう.農作業に和访る不良姿勢の改 善は，作物の生物学的制約が大きく, 工場労偅より困難 だが，リンゴでは矯化栽培により樹高を低くするなぞの 改良が行なわれている（立身，岩手医大）之の追加があ った．274 では, 作業面高と「つらさ」の中身との関連 について質問があった（鈴木，福島医大）が，実験で測 定された各筋の筋電困との関連で，身体各部位の自覚症 の評価が行なるれれば，打鍵作業に晾将る作業姿勢負担 軽減筮がより明確になるだろう。

演題 273 は, 手持ち工具使用時の上肢負担軽減を念頭 に括いた研究であったが, 工具の把握力を問題にする場 合には，各指の使われ方の要素を考虑すべきとの指摘 (肝付, 学砳) や, 工具の使われ方についての指摘 (井 谷, 岡山大) があった。研究目的からす机ば手指の使い 方や肢位など生体力学的負担要素を考慮すべきだが，演 者は, 今後, 演題 273 で竍告された, 腰痛予防のための 姿勢点や重量点に準じて，負担要素の点数化をはかり現 場作業の改善をはかる之述べた。

\section{5. 地域事業所における頸肩腕障害検診の検討} 赤松 隆, 古見耕一, 大嶺智子

(琉球大医成人保健)

昨年より，沖縄県における頸肩腕障害の実態把握を目 的飞各種の調查を開始しているが，得られた資料の前段 階的な活用を考光，今回は求め得见検診データのうち問 診表を中心としてそれらと加稌ならびに作業時間量との 関連より検討を行なった。

対象は, 從業員数約 1,500 名規模の事務系事業所以扩 ける，昭和 54 年より 56 年までに実施された頸肩腕障害 検診のららの延 118 例であるが，刘照群はいずれも打け 几機作䉪注事している平均年齢 $28.5 \pm 8.2$ 歲の女子 でいずれの毫例も過去に执いて著明な頸屃腕障害の症 状を有していたものはなく，をたすべて右利きの事例 のみである。

問猃の記入項目は和のおの3 段階に区分されたものそ れぞれに $0 ， 1 ， 2$ の得点を与えたが，部位別 21 項目 之全身 16 項目々の計 37 項目（当学会頸肩腕症候群委員 会作成のものを使用）の問診総和平均得点では $12.89 \pm$ 10.87 示し，さらに部位別 21 項目を左右に区分した 結果では右側で多少高い得点を示し有意差が認められ た．検診項目のうちの握力検査では右側がやや強くなっ て赫り左右有意差が認められた。年龄, 作業時間, 握 力, 問彰総和得点間での相関係数は, 個々の相関のいず れにおいても特徵的な所見は示されなかったが，年齢と 問䛦総和得点間で逆相関の傾向が示されていた。 作業時 間, 年龄之問診項目特の招のについての関連では, 内容 としては「肩こる」，「背こる」，「腰いたい」「目がつか れる」、「視力が赫ちた気がする」などの項目で比較的訴 党が多くなって蛒り，作業時間の延長により相対的な自 覚症状所見の得点の増加が認められた。一方, 年龄につ いては，経験年数の長い事例で必ずしも自覚症状を訴克 る頻度の上昇は認められず，か觉って若い年舲群で訴兄 が強い傾问が示された。

今後は, さらに対象を拡大し, 同一事例の経時的検討 を加光る予定である.

\section{6. 頸肩腕障害における暴露一作用/反応関係に関 する考察}

\section{前田勝義（久留米大医環衛）}

頸肩腕障害は虐業疲学と共通した側面を持ち, 頸肩腕 などに対する過重負担と結合した産業疲労が病的段階に 達したものと考光られる. 学基法施行規則第 35 条にお いてる，身体に過度の負担のかかる作乑態様に起因する 疾病と分類されている。しかし，本障害に和ける暴露 (量)一作用/反応関保化ついては発症要因の多様さが関 